\title{
SURGICAL TREATMENT OF SCHEUERMANN'S DISEASE BY THE POSTERIOR APPROACH. CASE SERIES
}

\author{
TRATAMENTO CIRÚRGICO DA DOENÇA DE SCHEUERMANN POR ACESSO \\ POSTERIOR. SÉRIE DE CASOS
}

\author{
TRATAMIENTO QUIRÚRGICO DE LA ENFERMEDAD DE SCHEUERMANN \\ POR VÍA POSTERIOR. SERIE DE CASOS
}

Antonio Hurtado Padilla', José Antonio Canales Nájera', Salvador de la Cruz Alvarez ${ }^{1}$, Fernando Guevara Villazón ${ }^{1}$

\begin{abstract}
Objective: To describe the results of surgical treatment of Scheuermann's disease by the posterior approach. Method: A descriptive, retrospective, longitudinal study in which patients with Scheuermann's disease, treated surgically by the posterior approach at the Hospital de Traumatologia y Ortopedia [Hospital for Traumatology and Orthopedics] "Lomas Verdes" IMSS. The Cobb method was used to measure the kyphosis in all the patients, of T5-T12. The surgical technique used was vertebral shortening by the Ponte osteotomy technique, at the apex of the deformity, accompanied by transpedicular instrumentation and posterior arthrodesis. Results: Five patients were included; three men and two women, with an average age of 16.6 years. The initial average kyphosis was $76^{\circ}$, which was corrected to $42^{\circ}$ after surgery. Blood loss was $590 \mathrm{ml}$, with a surgery time of 3 hours. Three patients were submitted to neurophysiological monitoring. No neurological lesion was found. There was no loss of correction at 6 months of evolution. Conclusions: The vertebral shortening technique with posterior instrumentation eliminates the use of the anterior approach to release the anterior longitudinal ligament. Osteotomies by the Ponte technique make the spine more flexible, and together with pedicular instrumentation, correct the deformity and preserve the correction over time.
\end{abstract}

Keywords: Scheuermann's disease; Kyphosis/surgery; Arthrodesis; Osteotomy.

\begin{abstract}
RESUMO
Objetivo: Descrever os resultados do tratamento cirúrgico da doença de Scheuermann por acesso posterior. Método: Estudo descritivo, retrospectivo e longitudinal, no qual foram incluídos pacientes com doença de Scheuermann tratados cirurgicamente por acesso posterior no Hospital de Traumatologia y Ortopedia "Lomas Verdes" IMSS. O método de Cobb foi utilizado para medir a cifose em todos os pacientes de T5-T12. A técnica cirúrgica utilizada foi encurtamento vertebral pela técnica de osteotomia de Ponte no ápice da deformidade, acompanhada por instrumentação transpedicular e artrodese posterior. Resultados: Foram incluídos cinco pacientes, três homens e duas mulheres, com média de idade de 16,6 anos. A cifose média inicial era de $76^{\circ}$ e foi corrigida para $42^{\circ}$ depois da cirurgia. O sangramento foi $590 \mathrm{ml}$, com tempo cirúrgico de 3 horas. Três pacientes foram submetidos à monitoração neurofisiológica. Não foi encontrada nenhuma lesão neurológica. Não houve perda da correção aos 6 meses de evolução. Conclusões: A técnica de encurtamento vertebral com instrumentação posterior elimina o emprego do acesso anterior para liberar o ligamento longitudinal anterior. A osteotomias pela técnica de Ponte flexibilizam a coluna e, em conjunto com a instrumentação pedicular, corrigem a deformidade e mantêm a correção no decorrer do tempo.
\end{abstract}

Descritores: Doença de Scheuermann; Cifose/cirurgia; Artrodese; Osteotomia.

\section{RESUMEN}

Objetivo: Describir los resultados del tratamiento quirúrgico de la enfermedad de Scheuermann por vía posterior. Método: Es un estudio descriptivo, retrospectivo longitudinal en el cual se incluyeron pacientes con enfermedad de Scheuermann manejados quirúrgicamente por vía posterior en el Hospital de Traumatología y Ortopedia "Lomas Verdes" IMSS. Se utilizó el método de Cobb para la medición de la cifosis en todos los pacientes de T5-T12. La técnica quirúrgica utilizada fue el acortamiento vertebral mediante osteotomías de Ponte en el ápice de la deformidad, acompañada de instrumentación transpedicular y artrodesis posterior. Resultados: Se incluyeron cinco pacientes, tres hombres y dos mujeres, con un promedio de edad 16,6 años. La cifosis inicial promedio fue de $76^{\circ}$ y corrigió a $42^{\circ}$ después de la cirugía. El sangrado promedio fue de $590 \mathrm{ml}$ con un tiempo quirúrgico de 3 horas. Se utilizó monitoreo neurofisiológico en tres de los pacientes. No se presentó ninguna lesión neurológica. No hubo pérdida de la corrección a los 6 meses de evolución. Conclusiones: La técnica de acortamiento vertebral con instrumentación posterior omite el abordaje anterior para la liberación del ligamento longitudinal anterior. Las osteotomías tipo Ponte flexibilizan la columna y junto con la instrumentación pedicular logran corregir la deformidad y mantenerla a través del tiempo.

Descriptores: Enfermedad de Scheuermann; Cifosis/cirugía; Artrodesis; Osteotomía.

1. Unidad Médica de Alta especialidad "Lomas Verdes" Instituto Mexicano del Seguro Social, Módulo de deformidades Vertebrales. Naucalpan, Estado de México.

Study conducted at the Instituto Mexicano del Seguro Social, Módulo de deformidades Vertebrales. Naucalpan, Estado de México.

Correspondence:Tlacotalpan 59-110 Colonia Roma Sur. Delegacion Cuahutemoc. CP 06760. México Distrito Federal. anthurtado@yahoo.com 


\section{INTRODUCTION}

Scheuermann's disease, also known as juvenile kyphosis, is a structural vertebral deformity that causes hyperkyphosis at the thoracolumbar level, due to the development of vertebral wedging during adolescence. ${ }^{1}$ It occurs in 0.4 to $0.8 \%$ of the population. Its exact etiology is not known, but a hereditary correlation has been found. ${ }^{2}$

Although the normal range of thoracic kyphosis varies, the Scoliosis Research Society defines the normal range as 10-40 degrees of kyphosis between T5 and T12. ${ }^{3}$

Wenger ${ }^{4}$ describes two types of juvenile kyphosis: the classic thoracic form, type 1, and the atypical thoracolumbar form, type 2. In type 1 juvenile kyphosis, the apex is usually between T1 and T8, and there are three or more vertebrae wedged more than 5 degrees. Type 2 thoracolumbar form has more irregularities, such as a decrease in the intervertebral spaces and anterior Schmorl's nodes. ${ }^{5}$

The usual symptom is dorsal or lumbar pain, which is particularly exacerbated by exercise, certain prolonged postures, or lifting heavy objects. The aesthetic deformity is another factor that prompts the patient to seek medical attention, although this is often delayed because the parents initially believes the problem to be postural. ${ }^{6}$

The most commonly used diagnostic criteria are: Wedging of more than $5^{\circ}$ in one or more vertebrae in the thoracic or thoracolumbar region, irregularity of the vertebral levels, decrease in the disc space, and kyphosis of more than 40 degrees. ${ }^{1}$

The pathophysiology consists of a modification of the epiphyseal growth phenomenon of the vertebral body, with molecular factors (collagen, proteoglycans) that eventually manifest as morphological changes. ${ }^{7,8}$

The history of the disease is usually benign. There are cases of angles of more than 100 degrees, when cardiopulmonary changes are present. ${ }^{9}$

The treatment objectives are to prevent progression, correct the deformity, alleviate the pain, and improve the patient's appearance. The management is dictated by the patient's age, the degree of deformity, and the symptoms. Treatment of kyphosis of less than 50 degrees is based on observation, to determine the progression of the deformity until the skeleton is mature. When the angle is greater, there is substantial growth remaining, and the vertebral deformity is flexible, a back brace is usually indicated. ${ }^{10}$

The criteria for indication of surgical management are: directly related neurological changes, kyphosis of more than 70 degrees, rapid progression of the curve, and pain that does not respond to conservative treatment. ${ }^{11,12}$ There are different surgical techniques for the correction; the double approach (anterior release and posterior instrumentation) and totally posterior techniques. The technique of vertebral shortening by Ponte osteotomy (also known as Smith-Petersen osteotomy) at the apex of the deformity, together with transpedicular instrumentation and posterior arthrodesis, has also been described, with good results and few complications. ${ }^{13}$

\section{MATERIAL AND METHOD}

The aim of this study is to analyze the results of 5 patients with Scheuermann's Disease treated surgically with single management via the posterior approach, in our hospital.

It is an observational, descriptive and retrospective study (Case series) carried out in the period 2013 to 2014, with a total of 12 patients diagnosed with Scheuermann's disease, who underwent surgery during the study period.

Clinical and radiological data were recorded for each patient, together with preoperative and intraoperative data, and postoperative data for a period of 6 months, which is why only these cases were included in this review. The Cobb method was used to measure the kyphosis before and after surgery. Radiographic studies were performed during hospitalization, after the surgery, and in the 3- to 6-year follow-up.

All the patients were submitted to the same surgical technique. To increase the flexibility of the deformity, Ponte type osteotomies were carried out. This technique involves removal of the facet joints and interspinal ligaments and the ligamentum flavum in the posterior spine, to accentuate the lordosis, creating flexibility, and avoiding what was previously done by performing release of the anterior longitudinal ligament by a second approach. The osteotomies were performed in all cases, at the apical level of 3 to 6 levels, depending on each case.

Posterior instrumentation was performed using the system of transpedicular screws and titanium rods. For the arthrodesis, an autologous bone graft was used, plus tricalcium phosphate. (Figure 1) A postoperative back brace was not used. Walking was indicated between 3 and 5 days after surgery. The patients were subsequently discharged to their homes.

The variables age, sex, symptoms, associated pathology, Wenger ${ }^{4}$ classification, initial Cobb angle (intra-observer measurement), Cobb angle after surgery, degrees corrected, and percentage degree of same, surgery time, surgical bleeding, and complications at 6 months were analyzed (infection, loss of anchorage, neurological damage, wound dehiscence).

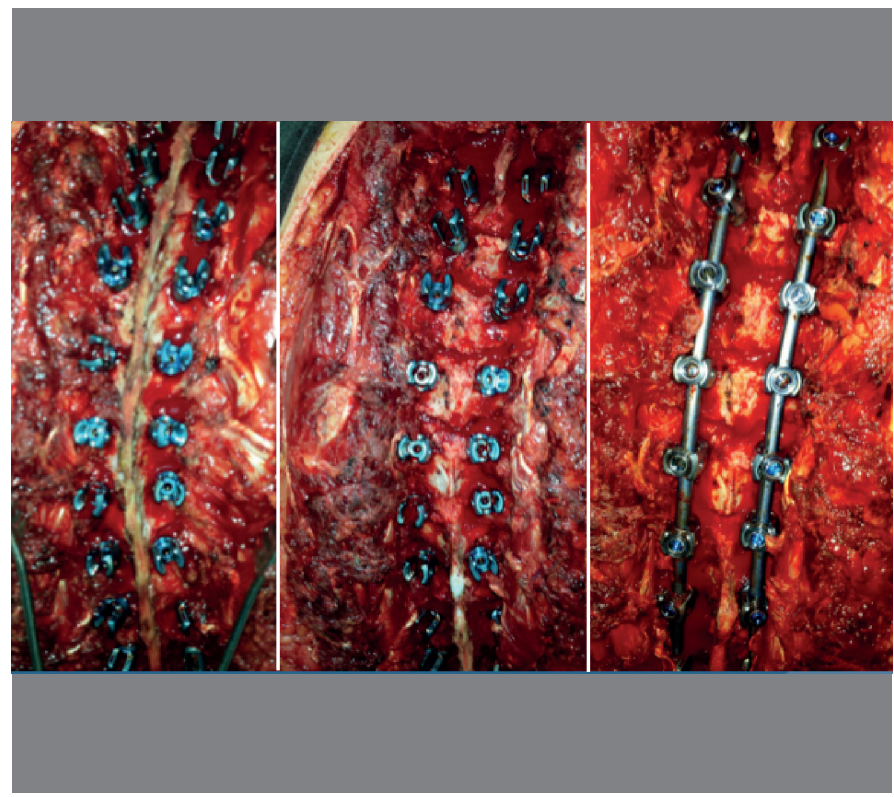

Figure 1. A) Placement of screws prior to the Ponte osteotomies. B) Ponte osteotomy. C) Final result of the instrumentation.

\section{RESULTS}

Of the 12 patients with Scheuermann's disease, five were operated on; two women and three men, with an average age of 16.6 years (14-21 years). Four patients had associated symptoms, particularly pain (lumbago and dorsal lumbago). (Table 1)

The patients were classified according to Wenger's classification. Three patients had type 1, the thoracic form, and two patients had type 2 , the thoracolumbar form.

The mean initial angle was $76.14^{\circ}\left(72.2^{\circ}-80.5^{\circ}\right)$. The mean postoperative angle was $42.22^{\circ}\left(37.4^{\circ}-50.1^{\circ}\right)$. The mean correction was $33.22^{\circ}\left(25.5^{\circ}-41.2^{\circ}\right)$, and the correction was maintained at the 6-month follow-up. (Figure 2)

The mean surgery time was 218 min (210-240) with mean surgical bleeding of $590 \mathrm{ml}$ (300-1200). In three of our patients, a neuromonitor was used during the surgery. None of our patients presented complications during or after the surgery, or at the 6-month follow-up. (Figure 3) 
Table 1. Describes the results obtained for the 5 patients, describing the variables analyzed and the surgical results.

\begin{tabular}{c|c|c|c|c|c|c|c|c|c|c}
\hline Patients & $\begin{array}{c}\text { Age } \\
\text { (years) }\end{array}$ & Sex & Symptomatology & $\begin{array}{c}\text { Classification } \\
\text { (Wenger) }\end{array}$ & $\begin{array}{c}\text { Initial } \\
\text { Cobb angle } \\
\text { (degrees) }\end{array}$ & $\begin{array}{c}\text { Postsurgical } \\
\text { angle (degrees) }\end{array}$ & $\begin{array}{c}\text { Correction } \\
\text { (degrees) }\end{array}$ & $\begin{array}{c}\text { Percentage } \\
\text { (orrection }\end{array}$ & $\begin{array}{c}\text { Surgery } \\
\text { time (min) }\end{array}$ & $\begin{array}{c}\text { Bleeding } \\
\text { (ml) }\end{array}$ \\
\hline 1 & 16 & Female & Lumbar pain & Type 1 & 80.1 & 43.3 & 36.8 & $54.06 \%$ & 210 & 300 \\
\hline 2 & 14 & Female & $\begin{array}{c}\text { Lumbar pain, } \\
\text { Marfan syndrome }\end{array}$ & Type 1 & 72.2 & 37.4 & 34.8 & $51.80 \%$ & 220 \\
\hline 3 & 15 & Male & $\begin{array}{c}\text { Asymptomatic, } \\
\text { Sotos syndrome }\end{array}$ & Type 1 & 80.5 & 39.3 & 41.2 & $48.82 \%$ & 210 \\
\hline 4 & 17 & Male & Dorsal-lumbar pain & Type 2 & 72.3 & 44.5 & 27.8 & $61.55 \%$ & 240 \\
\hline 5 & 21 & Male & Lumbar pain & Type 2 & 75.6 & 50.1 & 25.5 & $66.27 \%$ & 210 \\
\hline Means & 17 & & & & 76.14 & 42.92 & 33.22 & 560 \\
\hline
\end{tabular}

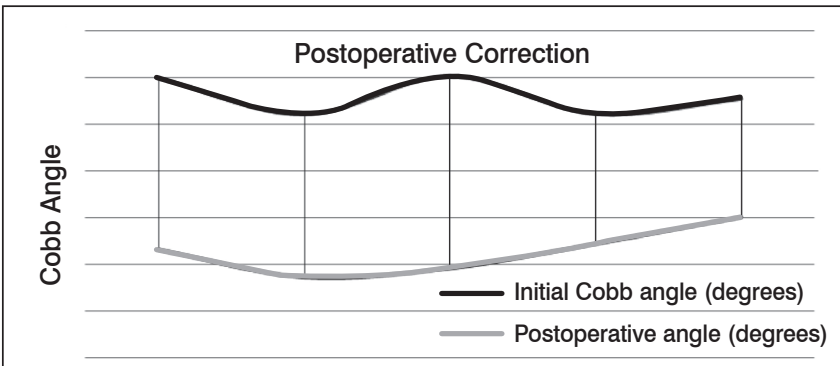

Patients

Figure 2. Relationship between initial correction vs. postoperative correction in our five patients.

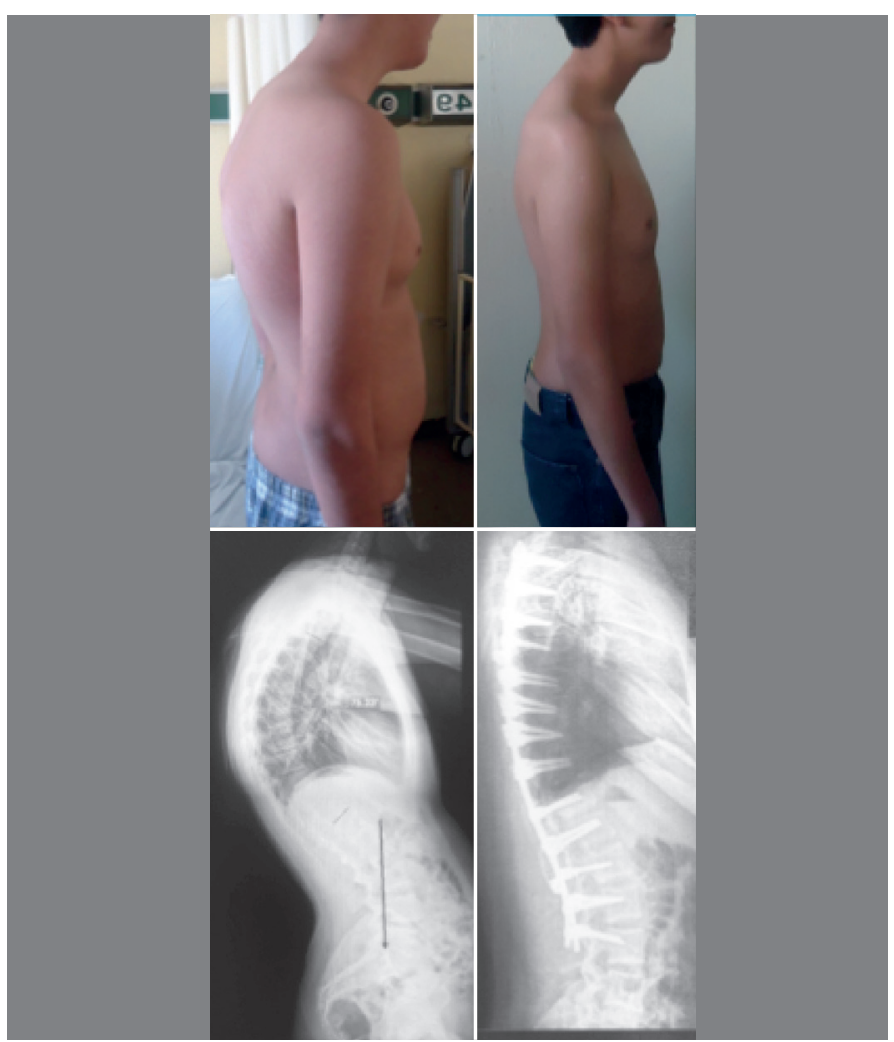

Figure 3. Clinical case of patient with Scheuermann's disease managed with single posterior approach, before and after surgery.
A comparison was carried out using the Student's t test for statistical analysis, comparing our results with those of a study by Hosman et al. ${ }^{14}$ (Table 2), in which 33 patients treated with single posterior instrumentation, and another group treated with anterior release and postoperative brace, were analyzed. Equality of variance with $p=0.9593$ was found, demonstrating comparable correlation of deformity correction.

\section{DISCUSSION}

Scheuermann's disease has been treated in different ways, and the treatment option we propose is the vertebral shortening technique with posterior instrumentation, which avoids the anterior approach for release of the anterior longitudinal ligament. Ponte osteotomies increase the flexibility of the spine and together with the pedicular instrumentation, are able to correct the deformity and maintain it over time.

Table 2. Student t statistical analyses, comparing our results with those of the study by Hosman et al. in 2003. ${ }^{14}$

\begin{tabular}{|c|c|c|c|c|c|c|}
\hline \multicolumn{7}{|c|}{ Two-Sample Independent $t$ Test } \\
\hline \multicolumn{7}{|c|}{ Input Data } \\
\hline \multirow{2}{*}{$\begin{array}{c}\text { Two-sided } \\
\text { confidence } \\
\text { interval }\end{array}$} & \multicolumn{4}{|c|}{$95 \%$} & & \\
\hline & $\begin{array}{l}\text { Sample } \\
\text { size }\end{array}$ & Mean & Std. Dev. & Std. Error & & \\
\hline Group-1 & 5 & 42.2 & 4.8 & 95 & & \\
\hline Group-2 & 33 & 55 & 9 & 95 & & \\
\hline Result & $t$ statistics & $d f$ & p-value ${ }^{1}$ & $\begin{array}{c}\text { Mean } \\
\text { Difference }\end{array}$ & $\begin{array}{l}\text { Lower } \\
\text { Limit }\end{array}$ & $\begin{array}{l}\text { Upper } \\
\text { Limit }\end{array}$ \\
\hline $\begin{array}{l}\text { Equal } \\
\text { variance }\end{array}$ & -0.0513549 & 36 & 0.9593 & -12.8 & -518.296 & 492.696 \\
\hline \multirow[t]{2}{*}{$\begin{array}{l}\text { Unequal } \\
\text { variance }\end{array}$} & -0.0952733 & 14 & 0.9254 & -12.8 & -300.952 & 275.352 \\
\hline & & F statistics & \multicolumn{2}{|c|}{$\begin{array}{l}d f \text { (numerator, } \\
\text { denominator) }\end{array}$} & \multicolumn{2}{|c|}{ p-value ${ }^{1}$} \\
\hline \multicolumn{2}{|c|}{$\begin{array}{l}\text { Test for equality of } \\
\text { variance }^{2}\end{array}$} & 6.6 & \multicolumn{2}{|c|}{32.4} & \multicolumn{2}{|c|}{0.07811} \\
\hline
\end{tabular}

1. p-value (two-tailed). 2. Hartley's $\mathrm{f}$ test for equality of variance. Results from OpenEpi, Version 3 open source calculator-t testMean 
Our results indicate that surgical correction of juvenile kyphosis using this technique results in few complications, satisfactory angular correction, and acceptable surgical times, days of hospitalization and intra-operative bleeding.

\section{CONCLUSIONS}

The management of corrective surgery of the spine requires the definition of evidence as to which is the best treatment option, particularly in diseases with low incidence involving high-risk procedures for the patient.

All authors declare no potential conflict of interest concerning this article.

\section{REFERENCES}

1. Schlenzka D, Arlet V. Juvenile kyphosis (Scheuermann's disease). In: Boos N, Max A, editors. Spinal disorders: fundamentals of diagnosis and treatment. New York: Springer; 2008. p. 765-93.

2. Damborg F, Engell V, Nielsen J, Kyvik KO, Andersen MØ, Thomsen K. Genetic epidemiology of Scheuermann's disease. Acta Orthop. 2011;82(5):602-5.

3. O'Brien MF, KukloTR, Blanke KM, Lenke LG, editors. Radiographic measurement manual: spinal deformity study group. Minneapolis: Medtronic Sofamor Danek; 2004.

4. Blumenthal SL, Roach J, Herring JA. Lumbar Scheuermann's. A clinical series and classification. Spine (Phila Pa 1976). 1987;12(9):929-32.

5. Edgren W, Vainio S. Osteochondrosis juvenilis lumbalis. Acta Chir Scand Suppl. 1957;227:1-47.

6. Ruiz-Santiago F, Moreno-Gaya M, Suárez-Boville I, López-Milena G, Rodríguez-Fernández C, Tristán-Fernández JM, et al. Evolución clinica y radiologica de la cifosis juvenil. Rehabilitación. 2003;37(1):11-6.

7. Palazzo C, Sailhan F, Revel M. Scheuermann's disease: an update. Joint Bone Spine. 2014;81(3):209-14.

8. Tomé-Bermejo F, Tsirikos Al. Current concepts on Scheuermann kyphosis: clinical presentation, diagnosis and controversies around treatment. Rev Esp Cir Ortop Traumatol. 2012;56(6):491-505.

9. Murray PM, Weinstein SL, Spratt KF. The natural history and long-term follow-up of Scheuermann kyphosis. J Bone Joint Surg Am. 1993;75(2):236-48.

10. Yamaguchi KT Jr., Andras L M, Lee C, Skaggs DL. Successful brace treatment of scheuermann's kyphosis in skeletally mature patients and severe kyphosis. Ann Orthop Rheumatol. 2014;2(2):1018

11. Poolman RW, Been HD, Ubags LH. Clinical outcome and radiographic results after operative treatment of Scheuermann's disease. Eur Spine J. 2002;11 (6):561-9.

12. Papagelopoulos PJ, Klassen RA, Peterson HA, Dekutoski MB. Surgical treatment of Scheuermann's disease with segmental compression instrumentation. Clin Orthop Relat Res. 2001;(386):139-49.

13. Geck MJ, Macagno A, Ponte A, Shufflebarger HL. The Ponte procedure: posterior only treatment of Scheuermann's kyphosis using segmental posterior shortening and pedicle screw instrumentation. J Spinal Disord Tech. 2007;20(8):586-93.

14. Hosman AJ, Langeloo DD, de Kleuver M, Anderson PG, Veth RP, Slot GH. Analysis of the sagittal plane after surgical management for Scheuermann's disease: a view on overcorrection and the use of an anterior release. Spine (Phila Pa 1976). 2002;27(2):167-75. 